\title{
The use of economic indicators from the Global Reporting Initiative by Spanish listed companies
}

\author{
María José García ${ }^{1}$, Marta Turró ${ }^{2}$, Oriol Amat $^{3}$ \\ ${ }^{1}$ Universidad Rey Juan Carlos, ${ }^{2}$ Universitat Pompeu Fabra (Spain) \\ mariajose.garcia@urjc.es, Martaturro.1991@gmail.com, oriol.amat@upf.edu
}

\begin{abstract}
Purpose: Corporate Social Responsibility (CSR) in companies is widely accepted within today's business community. However, the intangibility of this concept and the dispersion of related standards and regulations has created a context characterized by lack of homogeneity in the publishing of CSR results. The present study aims to determine the extent to which Global Reporting Initiative (GRI) indicators are used by Spanish listed companies.
\end{abstract}

Design/methodology/approach: An empirical analysis has been performed to asses and evaluate the 2011 CSR reports published by the companies listed on the IBEX-35, the Spanish stock exchange index which includes the most important listed companies. The analysis is centered exclusively on the economic indicators established by the GRI. The methodology used to interpret the results is based on the procedures of multivariate analysis, namely principal components analysis, correlation matrix, and hierarchical clustering.

Findings: The results of the study show that although the GRI tool is used extensively within the IBEX-35, the level of performance regarding the parameters established by the GRI varies depending on the studied company and indicator.

Research limitations/implications: This study focuses on the biggest Spanish listed companies; thus, the conclusions may differ in other geographic locations, as well as for smaller businesses.

Practical implications: This line of research helps to know more about the social reporting policies of big Spanish listed companies. 
Social implications: The evidence provided by this study helps to know more about the Corporate Social Responsibility policies and sustainability reports and declarations of social and environmental values governing their organizations.

Originality/value: This study is the first using principal component analysis in Spanish listed companies focusing in the economic indicators of the GRI.

Keywords: Corporate Social Responsibility, Global Reporting Initiative, Economic Indicators Jel Codes: M1

\section{Introduction}

During recent years, awareness and discussion about corporate social responsibility (CSR) by the business community has increased. The annual study elaborated by INSTITUTO UNIVERSITARIO DE ANÁLISIS ECONÓMICO Y SOCIAL (2011) provides various data points to interpret this increase. On the one hand, $84 \%$ of the population would refuse goods and services from companies that engage in inappropriate social and environmental behavior. On the other hand, the housing and financial crises as well as recent cases of corruption have damaged the reputations of several major organizations. Moreover, some environmental catastrophes caused by company actions have also resulted in increased social awareness, such as the case of the nuclear environmental catastrophe that took place in Fukushima, Japan in 2011.

This context has led to an increased incidence of company communications in the media and the proliferation of human and consumer rights defense groups. For this reason, companies have been increasingly publicizing their CSR policies by publishing the sustainability reports, codes of conduct, and declarations of social and environmental values governing their organizations.

In this study, we analyze the use of economic indicators from the Global Reporting Initiative (GRI) by companies on the selective IBEX-35 Spanish index. The purpose of the study is to analyze the amount of information collected by the companies in the sample in terms of economic indicators and then conduct a principal components multivariate analysis to determine whether there are causal relationships between company characteristics and the obtained results. The study also considers whether the degree of compliance is affected by company sectors, which is why hierarchical clustering analysis is performed.

The study is structured as follows. The second section presents a bibliographic review on the contributions made by different actors to CSR theory and its evolution in recent years. The third section analyzes the relationship between CSR and the financial performance of companies. Next, the empirical study is addressed. The employed methodology is explained in 
relation to sample selection and study design. Subsequently, the results are interpreted. The study ends with some conclusions derived from the performed analyses regarding the use of GRI economic indicators in companies listed on the IBEX-35.

\section{Literature review}

The strategic focus of CSR involves using a proactive business philosophy as an effective tool to compete and build competitive advantages in a changing environment. Therefore, carrying out a CSR strategy means securing a competitive and sustainable advantage (Porter \& Kramer, 2002) that is compatible with the company's ultimate goal: obtaining revenue.

The main theories on the practice of CSR found in the literature include the classical view, social contract theory, instrumental theory, legitimacy theory, and stakeholder theory. With regard to the classical view of CSR, Friedman (1962) states that companies do not have any responsibilities beyond legally earning profits. According to this premise, CSR may incur additional costs and could therefore negatively impact an organization's overall performance and sustainability (Carroll, 1999).

The central idea of the social contract theory is based on how companies relate to society. According to this theory, companies should act responsibly not only because they have a commercial interest in doing so, but also because it is how society implicitly hopes companies will behave (Moir, 2001). Moreover, according to this theory, companies are considered to be social institutions and should establish alliances with other social structures, such as families, educational systems, and social organizations (such as non-governmental institutions (NGOs) or religious institutions) to help improve the lives and meet the needs of the general population. In other words, the social contract theory holds that business and society are equal partners, each enjoying a set of rights and having reciprocal responsibilities. According to this paradigm, there are direct and indirect mutual needs between companies and society.

In an attempt to further legitimize the role of companies in society, the instrumental theory considers CSR to be a strategic tool that can be used to reach economic goals through the creation, improvement, and enhancement of competitive advantages. Proponents of this theory argue that companies can choose to support some social programs to generate a competitive advantage or for other strategic reasons without endangering the interests of key stakeholders or shareholders. Supporting certain actions that produce social benefits improves the company's competitiveness because social and economic benefits are related. According to this premise, the main motivation for CSR is to ensure that companies establish competitive advantages (Porter \& Kramer, 2002). 
Legitimacy theory asserts that CSR is a response to environmental pressures that involve social, political, and economic forces. According to this theory, companies are set up and organized with an institutional focus, coming to be seen as social organizations and resource coordinators with the ability to influence the tastes and preferences of consumers in terms of public opinion and even legislation. In this context, the behavior of business organizations has to be adjusted to the value system existing in the society where they operate, considering the broadest view of societal expectations and transmitting maximum reliability regarding their actions to interest groups. In this sense, companies may even influence societal rules and expectations, provided that they share the society's value system. For this reason, according to this theory, organizations to seek balance their actions and how they are able to convey to society that their actions and behaviors are the most appropriate (Suchman, 1995).

A different approach to the definition and development of CSR is provided by stakeholder theory. According to this approach, the way to develop socially responsible behavior on the part of organizations is to address the needs and rights of all stakeholders whose interests relate to the company (Freeman, 1984; Evan \& Freeman, 1993; Donaldson \& Preston, 1995; Harrison \& Freeman, 1999; Maignan \& Ferrell, 2004; Friedman \& Miles, 2006). According to the paradigm developed by this theory, CSR is analyzed from the perspective of corporate citizenship (Maignan \& Ferrell, 2001; Matten, Crane \& Chapple, 2003; Matten \& Crane, 2005), in which companies are regarded as belonging to a community and therefore interact with community members (Altman, 1998). According to the stakeholder theory perspective, a company should manage its CSR strategies from the dual perspectives of creating value both for the company and its stakeholders.

However, as mentioned at the beginning of the present literature review, we cannot forget the company's ultimate goal, generating revenue. This is why we analyze the relationship between CSR and financial performance within the context of our study examining the use of GRI economic indicators among companies listed on the IBEX-35.

\section{Relationship between CSR and financial performance}

The relationship between CSR and financial performance has been analyzed since the 1970s without reaching a consensus. The diversity of concepts that are included in CSR, the lack of a common definition, the lack of consistent application by companies and the difficulties related to measurement (Garriga \& Melé, 2004) explain why it is so challenging to conduct statistical studies on CSR and profitability.

However, analyses and research continue to be conducted to examine whether there is a direct relationship between CSR and the financial performance of companies. Some authors find a positive relationship (Waddock \& Graves, 1997; Fombrum \& Stanley, 1990; Roberts \& Dowling, 
2002; Allouche \& Laroche, 2005; Poddi \& Vergalli, 2009), Larrinaga (1997), Fernández and Larrinaga (2007), Moneva and Hernández (2006) and Moneva (2007); some others find a negative relationship (McWilliams \& Siegel, 2000; Wright \& Ferris, 1997; Jensen, 2002; Nelling \& Webb, 2009), and yet others find no relationship at all (Aupperle, Caroll \& Hatfield, 1985; McWilliams \& Siegel, 2001). Although none of the mentioned studies can be regarded as conclusive, in general, there is some consensus in favour of a positive direct relationship (being discrete in some cases) between these two variables (Walsh, Weber \& Margolis, 2003; Orlitzky, Schmidt \& Rynes, 2003).

If we accept that the relationship between CSR and financial performance is indirect and occurs through other mediating variables (Surroca, Tribó \& Waddock, 2010), the question we must ask is how to identify these variables. Companies' social behaviors, reputations, corporate cultures, and levels of intangible assets are variables that can directly affect the profitability of CSR and financial performance.

Consequently, in recent years, different tools and guides have emerged with the purpose of standardizing data collection for and preparation of CSR reports. In this sense, the "Guide for Preparing Sustainability Reports" by the GRI (2011) is one of the tools with the highest application rates. In the ranking of countries that use this application, Spain's position is noteworthy, ranking second after the United States. This is why we considered it appropriate to use the GRI as a reference in the study of the CSR reports of companies on the IBEX-35.

The GRI contains 81 global indicators, in addition to business sector indicators, corresponding to six areas: economic action, environmental action, labor practices and work ethics, human rights, social responsibility, and product responsibility.

In relation to the selected scope of application by companies listed on the IBEX-35, we note that various previous studies have examined sustainability reports elaborated under GRI criteria. In this regard, we should note the study on CSR and corporate governance of Arjona and Lozano (2009) and the analysis of CSR information issued by companies of Vázquez and Cordero (2007). In the economic context (where this study is developed), De los Ríos, Torres, Tirado and Carbonell (2009) conducted a study aimed at explaining the value generated by companies listed on the IBEX-35 based on a series of indicators representative of their main stakeholders. Although GRI indicators were also used in the study, because it was focused on the relationship between generated value and stakeholders, no economic indicators were used. Last, Arimany, Puigvi and Sabatta (2013) conducted a descriptive analysis of financial indicators for non-financial companies on the IBEX-35. In the study, no correlations were found between financial information and financial CSR indicators, although the focus was not on economic indicators.

Given the above, we believe that this research is novel with respect to previous studies. 


\section{Empirical study}

\subsection{Introduction to the study}

After analyzing the theoretical context, this section discusses an empirical study on the economic GRI indicators contained in the 2011 CSR reports of companies listed on the IBEX35. First, we analyze the general extent to which the GRI model is used. Next, the results obtained for the new economic indicators are interpreted through principal components analysis. Last, we study the possible relationship between the characteristics of each company and the results derived from the study. The employed methodology is based on multivariate analysis tools (Peña, 2002).

Due to the limited scope of the study, the analysis focuses on the economic field because it includes a broader range of indicators.

\subsection{Use of the GRI Guide for Preparing Sustainability Reports}

First, the analysis considers the widespread use of the GRI by companies listed on the IBEX35. Currently, $88.57 \%$ of CSR reports published by these companies are based on GRI criteria, of which $83.87 \%$ have obtained an independent verification report issued by an auditing agency. The remaining $11.43 \%$ of companies that do not use this method have been excluded from the study to avoid distortions in the results.

In addressing the sectoral analysis, we observe that $100 \%$ of the companies belonging to the oil and energy and financial and real estate services sectors prepared their sustainability reports under the scope of the GRI parameters, whereas in the consumer goods sector, these parameters were only followed by $33.33 \%$ of companies, as shown in Figure 1.

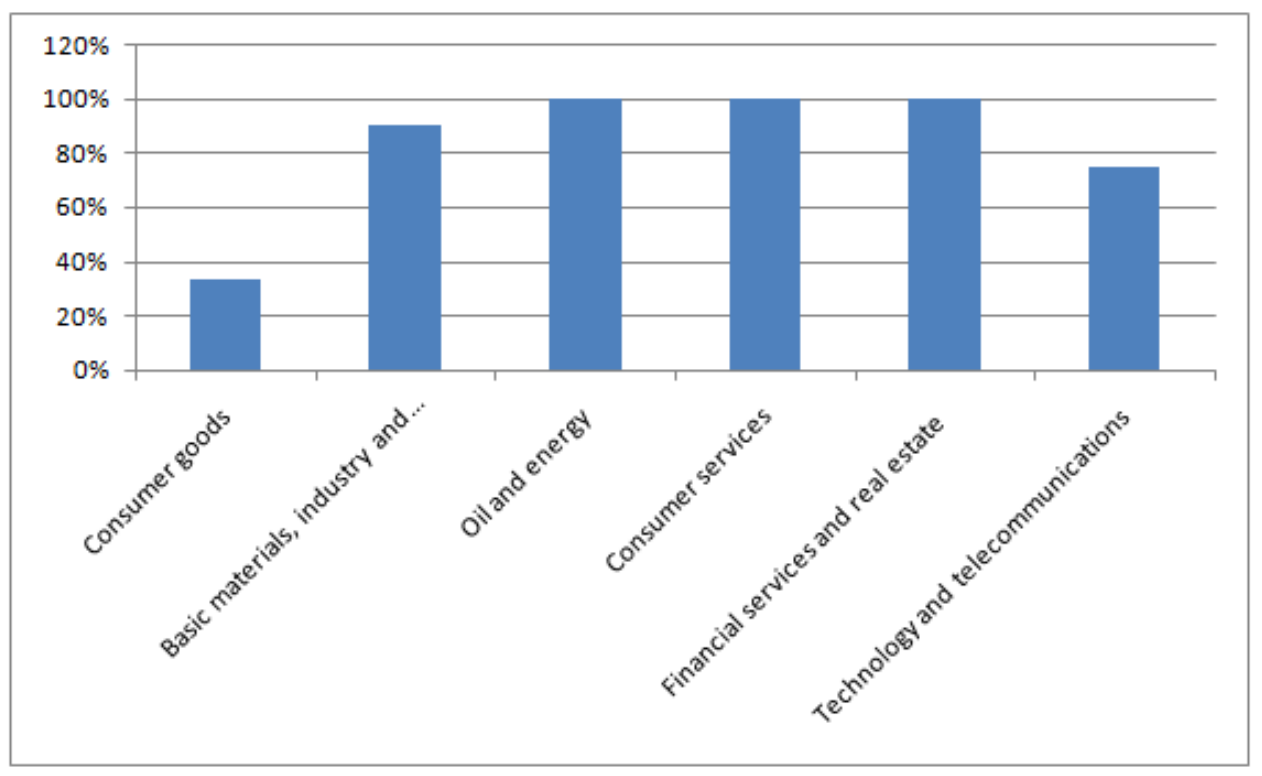

Figure 1. Sectorial dispersion of GRI application 


\subsection{Analysis ofGRI economic indicators}

The GRI economic indicators that were employed by the sample companies were analyzed after excluding companies that did not use GRI indicators when preparing sustainability reports. The methodology used in the analysis consisted of evaluating the presence of these indicators. Depending on the degree of compliance with the parameters set by GRI, each indicator was rated for each company using the Likert scale established by the Observatorio de la Responsabilidad Social Corporativa (2009). This scale ranges from 0 to 5, where a score of "0 - inexistent" indicates that information related to the evaluated aspects is inexistent and "5 exhaustive" indicates that much information relevant to the aspects mentioned above is detected.

The most relevant results of the analysis are presented in the following table:

\begin{tabular}{|c|c|c|}
\hline Indicator & Score & Observations \\
\hline $\begin{array}{l}\text { EC1 Direct economic value created and distributed, } \\
\text { including revenues, operating costs, other community } \\
\text { investments, retained earnings, and payments to capital } \\
\text { providers and governments. }\end{array}$ & 3.3 & All companies report this indicator. \\
\hline $\begin{array}{l}\text { EC2 Financial consequences and other risks and } \\
\text { opportunities for the organization's activities due to } \\
\text { climate change. }\end{array}$ & 2.6 & $\begin{array}{l}\text { High dispersion score. The companies that } \\
\text { obtained a high score participate in the Carbon } \\
\text { Disclosure Project. }\end{array}$ \\
\hline $\begin{array}{l}\text { EC3 Covering the organization's obligations to social } \\
\text { benefit programs. }\end{array}$ & 3.29 & $\begin{array}{l}\text { Most companies provide detailed information in } \\
\text { their annual reports due to accounting standards } \\
\text { requirements. }\end{array}$ \\
\hline $\begin{array}{l}\text { EC4 Significant financial assistance received from } \\
\text { governments. }\end{array}$ & 3.42 & $\begin{array}{l}\text { This indicator had a high average score }(3.42) \text { and } \\
\text { an atypically low standard deviation }(0.96) \text {. }\end{array}$ \\
\hline $\begin{array}{l}\text { EC5 Dimension for the relationships between standard } \\
\text { initial wages by gender and relative to local minimum } \\
\text { wage (sites where significant activities are performed). }\end{array}$ & 1.58 & $\begin{array}{l}\text { Because it was treated as an optional indicator, it } \\
\text { obtained a low average score }(1.58) \text {, but it should } \\
\text { be noted that it is used by } 58 \% \text { of the sample. }\end{array}$ \\
\hline $\begin{array}{l}\text { EC6 Policies, practices, and proportion of spending on } \\
\text { local suppliers (sites where significant activities are } \\
\text { performed). }\end{array}$ & 3.27 & $\begin{array}{l}\text { All companies report this indicator but only } 3.22 \% \\
\text { of the sample details the approval process for } \\
\text { suppliers and includes a relationship between the } \\
\text { number of bids and contracted local suppliers. }\end{array}$ \\
\hline $\begin{array}{l}\text { EC7 Procedures for local hiring and proportion of senior } \\
\text { management hired from the local community (sites } \\
\text { where significant activities are performed). }\end{array}$ & 3.69 & $\begin{array}{l}\text { This indicator has an atypically low standard } \\
\text { deviation(1.09), which indicates that companies } \\
\text { behave similarly in publishing this information. } \\
\text { However, it must be noted that most companies } \\
\text { state that they do not use specific procedures for } \\
\text { local hiring because they seek to promote plurality } \\
\text { on teams. }\end{array}$ \\
\hline $\begin{array}{l}\text { EC8 Development and impact of investment in } \\
\text { infrastructure and services provided for public benefit } \\
\text { through commercial and in-kind agreements. }\end{array}$ & 0.78 & $\begin{array}{l}\text { The low rate achieved in this indicator is because } \\
\text { most companies do not include the negative } \\
\text { impact of investments made. }\end{array}$ \\
\hline $\begin{array}{l}\text { EC9 Understanding and description of significant indirect } \\
\text { economic impacts, including the scope of these impacts. }\end{array}$ & 1.56 & $\begin{array}{l}\text { The behavior for EC9 is similar to that for EC5 } \\
\text { because both are optional indicators. }\end{array}$ \\
\hline
\end{tabular}

Table 1. Analysis of GRI economic indicators used by companies listed on the IBEX-35 


\subsection{Principal component analysis}

A matrix was elaborated from the scores obtained for each company in the sample for each of the nine indicators. A principal component analysis was applied to this matrix with the goal of facilitating the interpretation of the data and synthesizing the disperse information contained in the original matrix into a few variables. The new variables chosen were those that predicted the original data more accurately (had the highest correlation) and that also explained most of the information (including a greater part of the variance in the data).

In the study, we switched from a matrix with nine variables to another having only two principal components. These components are the first two indicators that explain a greater portion of the original variance in the data. Specifically, the first and second components explain $32.72 \%$ and $15.53 \%$ of the variance, respectively, as shown in Figure 2 . The figure shows the percentage of variance for each principal component, and it can be observed that for each new component, the proportion explained is lower.

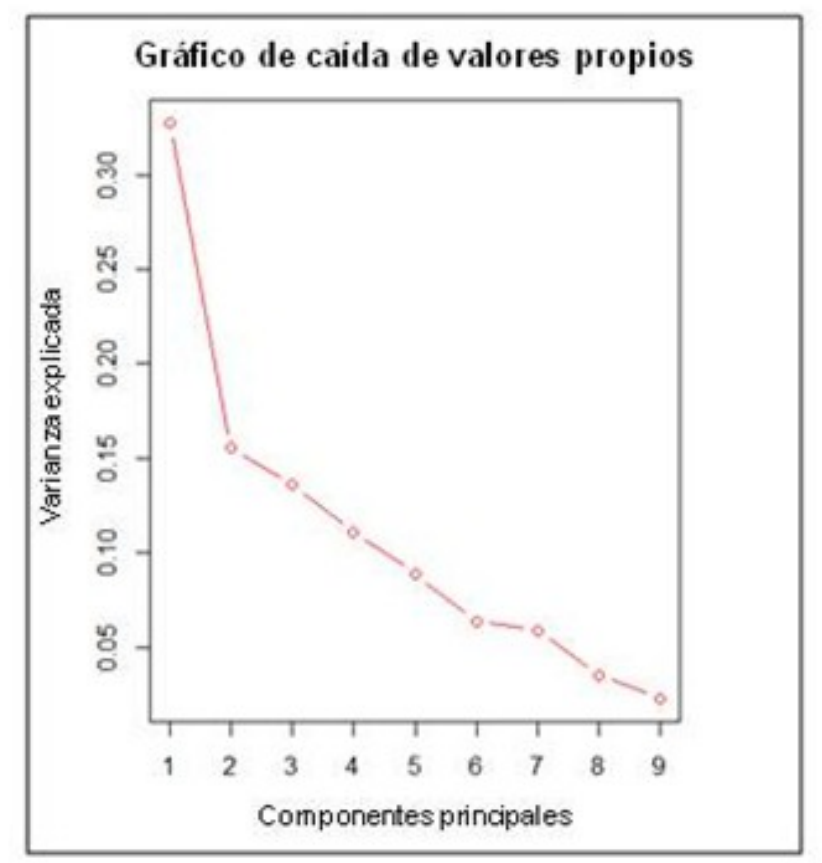

Figure 2. Graph showing the decreasing values corresponding to variance explained versus main components

With these data, a new matrix is obtained including 31 individuals (rows) and two variables (the columns represent the first and second principal components). In this way, the matrix goes from having 279 data elements to having 62, thus facilitating the analysis of the results. 
To interpret the principal components, it is necessary to know which variables they contain in higher proportions. For this reason, the correlation between each principal component and each GRI economic indicator is examined. The following table lists these correlations.

\begin{tabular}{|l|c|c|}
\cline { 2 - 3 } \multicolumn{1}{l|}{} & \multicolumn{1}{c|}{ CP1 } & CP2 \\
\cline { 2 - 3 } & $\begin{array}{c}\text { Degree of general } \\
\text { compliance }\end{array}$ & $\begin{array}{c}\text { Consequences of } \\
\text { climate change }\end{array}$ \\
\hline $\begin{array}{l}\text { EC1 Direct economic value generated and } \\
\text { distributed }\end{array}$ & 0.11 & 0.14 \\
\hline EC2 Consequences of climate change & 0.61 & 0.73 \\
\hline $\begin{array}{l}\text { EC3 Covering obligations in social benefits } \\
\text { programs }\end{array}$ & 0.4 & -0.35 \\
\hline EC4 Financial support from governments & 0.24 & -0.12 \\
\hline $\begin{array}{l}\text { EC5 Relations between standard initial } \\
\text { wage and local minimum wage }\end{array}$ & 0.76 & -0.34 \\
\hline EC6 Relations with local suppliers & 0.61 & -0.31 \\
\hline EC7 Local hiring & 0.37 & -0.41 \\
\hline $\begin{array}{l}\text { EC8 Impact of investments on public } \\
\text { benefits }\end{array}$ & 0.54 & 0.32 \\
\hline EC9 Indirect economic impacts and scope & 0.71 & 0.02 \\
\hline
\end{tabular}

Table 2. Correlations between the GRI indicators and the principal components

CP1 indicates the degree of overall compliance, and it is observed that the correlations with the original variables are all positive. However, not all of the indicators within this new variable have the same weight. EC5 and EC9 are the most prevalent indicators, with correlations above 0.7; in comparison, EC1 andEC4 have lower incidences, showing correlations below 0.25. CP2 mainly capturesEC2, which has a correlation of 0.73 .

The biplot summarizes the results in a more visual way. The Figure 3 has the first two principal components as coordinates and shows the relative positions of the companies listed on the IBEX-35. Moreover, it shows the vectors (red arrows) that represent the studied variables; the length and direction indicate the correlation with the principal components shown in the table above. 


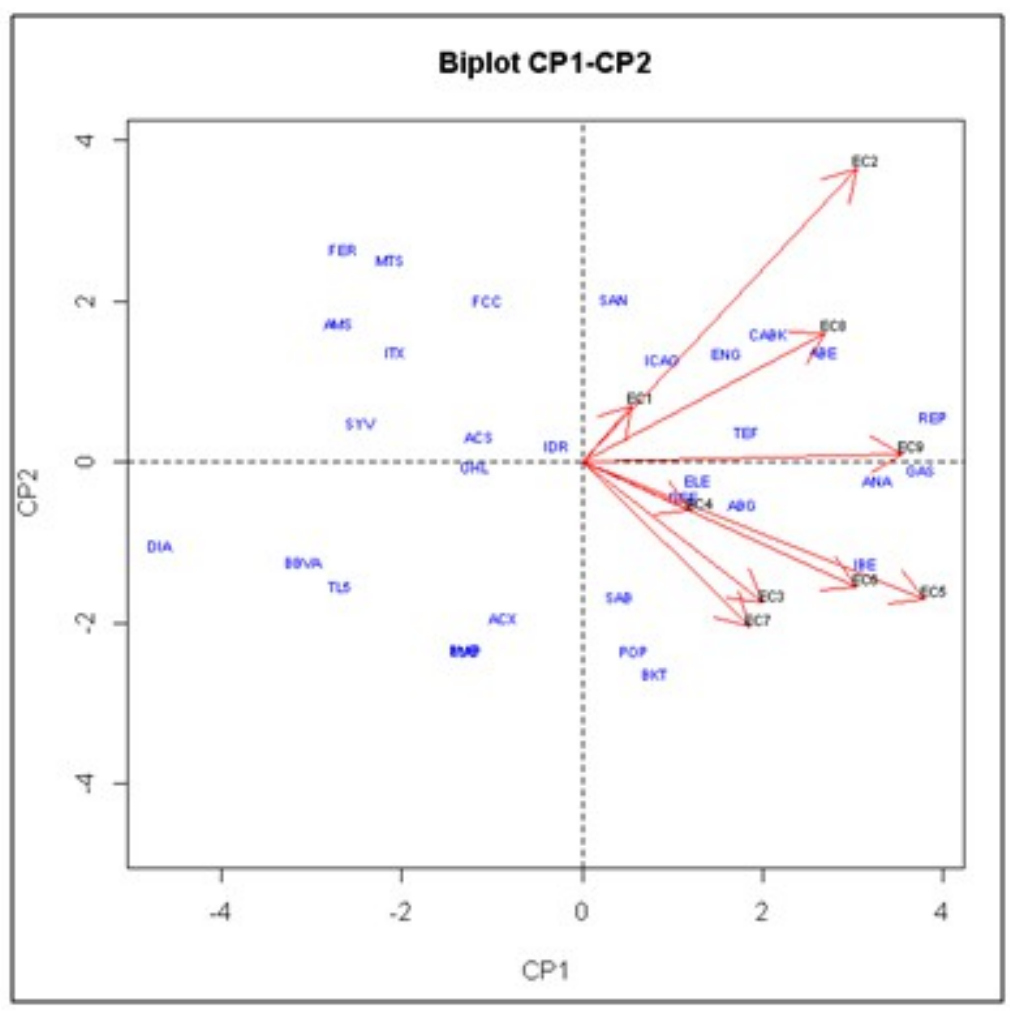

Figure 3. Biplot graph of principal components

Regarding CP1, the graph distinctly shows two groups. On the extreme right of the axis are the companies that clearly publish all the economic indicators, particularly EC5 and EC9. On the opposite side lie the companies that issue more limited information regarding the GRI parameters.

Regarding CP2, the upper end of the graph shows those companies that meet the climate change requirements, i.e., Santander Bank and Ferrovial. In contrast, Bankinter, Mapfre, BME and Popular are found on the lower end, indicating that they release less detailed information about the effects of climate change.

In conclusion, the information contained in the original data matrix can be summarized as follows. First, it reflects the degree of general compliance with the GRI parameters (with a higher incidence of optional indicators), and second, it shows the extent to which the effects of climate change are assimilated within the structure of the company. 


\subsection{Relationship between company characteristics and results}

To determine whether the specific characteristics of the listed companies affect the scores obtained in the study, new variables have been introduced: four numerical variables (turnover, net profit, international presence, and number of employees) and one qualitative variable (business sector). Because of the nature of the data, the methodology used in this section is based on two statistical procedures: a correlation matrix for the numerical variables and hierarchical clustering for the qualitative variable.

The following table shows the correlations between these variables and the principal components obtained in the previous section. As mentioned above, the correlation between the two variables indicates the strength and direction of the linear relationship.

\begin{tabular}{|l|r|r|}
\cline { 2 - 3 } \multicolumn{1}{c|}{} & \multicolumn{1}{c|}{$\begin{array}{c}\text { CP1 } \\
\text { Degree of overall } \\
\text { compliance }\end{array}$} & $\begin{array}{c}\text { CP2 } \\
\text { Consequences } \\
\text { of climate } \\
\text { change }\end{array}$ \\
\hline Turnover & 0.15 & 0.32 \\
\hline Net profit & 0.19 & 0.20 \\
\hline Annual change in price & 0.16 & -0.14 \\
\hline International presence & -0.10 & 0.40 \\
\hline Number of employees & -0.18 & 0.36 \\
\hline
\end{tabular}

Table 3. Correlation between company characteristics and principal components

At first glance, the table shows that there are no strong correlations between any of the analyzed variables and the corresponding principal components. However, the first component has a positive correlation with net profit and a negative correlation with number of employees. This would imply that the more profit the company obtains, the better the company follows the parameters established by the GRI. Similarly, the more workers the company has, the lower the rate of compliance (specifically for optional indicators). However, both relationships are weak (below 0.2).

In contrast, the second principal component has stronger correlations. The positive correlations with international presence (0.4), number of employees $(0.36)$, and turnover $(0.32)$ are noteworthy. This indicates that larger companies tend to be more precise in publishing information on theEC2 indicator, which records the effect of climate change on the company.

\subsubsection{Hierarchical grouping}

As stated above, the qualitative variable introduced in the study is the business sector. First, the 31 companies were assigned to the business sector to which they belonged, according to the classification used by the Spanish Stock Exchange, which distinguishes among "oil and 
energy", "basic materials, industry and construction", "consumer goods", "consumer services", "financial services and real estate", and "technology and telecommunications".

The employed analysis procedure is hierarchical grouping, which aims to classify the set of individuals (the 31 companies) according to similarities. Through an analysis of the distances between individuals, the most homogeneous groups possible are obtained (intra-group resemblance) but with the relationship between the most heterogeneous groups possible (inter-group difference). There are different grouping criteria, each of which establishes a definition of distance. Simple, complete, average, and ward are the most common of these. Different studies have been carried out on the effectiveness of these methods, and it has been determined that none of the criteria are optimal in $100 \%$ of cases. Nevertheless, Blashfield (1976) concluded that in most situations, ward is the most effective criterion, followed by complete. Furthermore, Rokach and Maimon (2005) found that the complete method generates more compact groups and more useful hierarchies. For this reason, the complete criterion, which defines distance as the distance between the farthest individuals, was chosen. The dendrogram (Figure 4) shows the classifications resulting from hierarchical grouping.

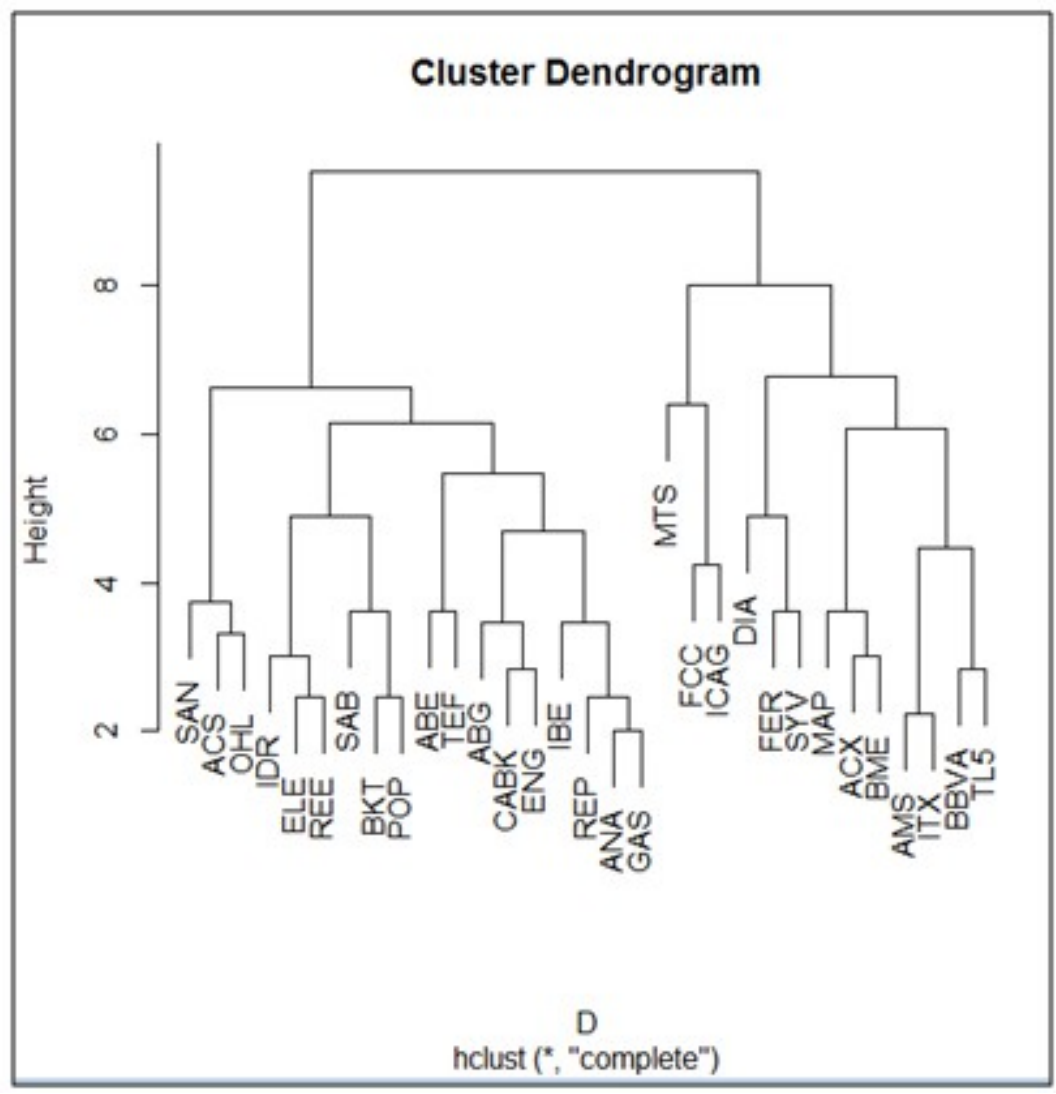

Figure 4. Dendrogram cluster derived from hierarchical grouping 
The following contingency table shows a comparison between groups derived from the analysis using the original classification (sectors according to the Spanish Stock Exchange).

\begin{tabular}{|l|c|c|c|c|c|c|}
\hline $\begin{array}{c}\text { Hierarchical } \\
\text { grouping / } \\
\text { sector }\end{array}$ & $\begin{array}{c}\text { Oil and } \\
\text { energy }\end{array}$ & $\begin{array}{c}\text { Basic materials, } \\
\text { industry and } \\
\text { construction }\end{array}$ & $\begin{array}{c}\text { Consumer } \\
\text { goods }\end{array}$ & $\begin{array}{c}\text { Consumer } \\
\text { services }\end{array}$ & $\begin{array}{c}\text { Financial } \\
\text { services and } \\
\text { real estate }\end{array}$ & $\begin{array}{c}\text { Technology and } \\
\text { telecommunications }\end{array}$ \\
\hline Group 1 & 6 & 2 & 0 & 1 & 4 & 2 \\
\hline Group 2 & 0 & 1 & 1 & 1 & 3 & 1 \\
\hline Group 3 & 0 & 2 & 0 & 0 & 1 & 0 \\
\hline Group 4 & 0 & 1 & 0 & 0 & 0 & 0 \\
\hline Group 5 & 0 & 2 & 0 & 1 & 0 & 0 \\
\hline Group 6 & 0 & 1 & 0 & 1 & 0 & 0 \\
\hline
\end{tabular}

Table 4. Contingency table for groups resulting from hierarchical grouping and economic sectors

As we can see, the groups resulting from hierarchical clustering are heterogeneous in terms of the number of constituent members: Group 1contains $48.39 \%$ of the sample, whereas Group 6 only has two constituent members. Nevertheless, the table provides some relevant results. It is observed that all the members of the oil and energy sector are found within the same group (Group 1), meaning that they behave similarly in publishing GRI economic indicators. However, there are sectors with dispersed members, as in the cases of the basic materials, industry and construction sector, which has members in all the groups of the hierarchical clustering, and the consumer services sector, for which there is not a single case in which members are in the same group. The consumer goods sector cannot be compared because it only has one member (because the remaining companies in this sector do not prepare CSR reports and have therefore been excluded from the sample). Last, the financial services and real estate and technology and telecommunications sectors are in an intermediate position: half of the members are in the same group.

Therefore, it is seen that in some industries, such as oil and energy, all constituent members behave in a similar fashion, while in others, such as consumer services, the opposite occurs.

\section{Conclusions}

Our empirical study has allowed us to respond to the proposed objectives. The most relevant results derived from the present study are as follows.

The results of the analysis show that there is extensive use of the GRI among the companies listed on the IBEX-35; this tool is used by $88.57 \%$ of these companies. Particularly noteworthy are the oil and energy, consumer services and financial services and real estate sectors, where GRI is applied in $100 \%$ of cases. In contrast, the level of use in the consumer goods sector is only $33.33 \%$. 
Not all companies comply with each of the parameters established by the GRI, and the degree of compliance varies depending on the indicator. In this sense, whereas information relating to the EC4 indicator obtained a higher average score (3.42), the average scores for the optional EC5 and EC9 indicators were substantially lower, at 1.58 and 1.68 respectively.

Principal component analysis has enabled the information from our study to be synthesized, indicating the main differences in the analyzed reports. Essentially, two factors were detected. The most prevalent factor was the first principal component, which indicates the general performance level for the GRI parameters. In contrast, the second principal component mostly indicates the extent to which the effects of climate change are assimilated within a company's structure.

With regard to the relationship between company characteristics and results, it can be stated that it is very weak. Even so, a positive correlation was found between the size of the company (international presence, number of employees and turnover) and the second principal component, which refers to the effects of climate change.

With regard to the sector variable, after analyzing the groups resulting from hierarchical clustering, it was concluded that in certain industries, such as oil and energy, the constituents exhibit similar behavior, whereas in others, such as the consumer services sector, each of the constituent members is in a different group.

Therefore, the study showed that despite the different criteria for CSR accounting, the publication of this information by companies listed on the IBEX-35 is quite homogeneous because most companies follow the model established by the GRI. Still, there are some differences depending on the examined company or indicator.

This study has some limitations, among them it can be said that it focuses on the biggest Spanish listed companies; thus, the conclusions may differ in other geographic locations, as well as for smaller businesses. 


\section{References}

ALLOUCHE, J.; LAROCHE, P. (2005). A Meta-Analytical Investigation of the Relationship between Corporate Social and Financial Performance. Revue de Gestion des Ressources Humaines, 57: 18-41.

ALTMAN, B. (1998). Corporate community relations in the 1990s: a study in transformation. Business and Society, 37(2): 221-227. http://dx.doi.org/10.1177/000765039803700205

ARIMANY, N.; PUIGVI, S.; SABATTA, A. (2013). Análisis de los indicadores RSC/indicadores financieros en las empresas no financieras del IBEX 35. Revista Internacional de Género y Comercio, $\mathrm{XI}(21)$ : 1-9.

ARJONA, C.; LOZANO, J.M. (2009). La RSE en el gobierno corporativo de las sociedades del Ibex-35, un análisis de transparencia. ESADE, Instituto de Innovación Social.

AUPPERLE, K.; CAROLL, A.; HATFIELD, J. (1985). An empirical examination of the relationship between corporate social responsibility and profitability. Academy of Management Journal, 28(2): 446-463. http://dx.doi.org/10.2307/256210

BLASHFIELD, R.K. (1976). Mixture model tests of cluster analysis: Accuracy of four agglomerative hierarchical methods. The Psychological Bulletin, 83(3): 377-388. http://dx.doi.org/10.1037/0033-2909.83.3.377

CARROLL, A.B. (1999). Corporate social responsibility: Evolution of a definitional construct. Business and Society, 38(3): 268-295. http://dx.doi.org/10.1177/000765039903800303

DE LOS RÍOS, A.; TORRES, M.; TIRADO, P.; CARBONELL, A. (2009). Stakeholders, intangibles y generación de valor en las empresas del IBEX 35: una estimación mediante datos de panel. Revista Española de Financiación y Contabilidad, XXXVIII(142): 239-263.

DONALDSON, T.; PRESTON, L. (1995). The stakeholder theory of the corporation: concepts, evidence and implications. Academy of Management Review, 20(1): 65-91.

EVAN, W.M.; FREEMAN, R.E. (1993). A stakeholder theory of the modern corporation: Kantian capitalism. In T.L. Beauchamp \& N.E. Bowie (eds.), Ethical Theory and Business (pp.75-84). Englewood Cliffs, NP: Prentice-Hall.

FERNÁNDEZ, M.; LARRINAGA, C. (2007). Memòries de sostenibilitat: Responsabilitat i transparència. Revista de Comptabilitat i Direcció, Responsabilitat Social Corporativa, 27: 39-54.

FREEMAN, E. (1984). Strategic Management: A Stakeholder Approach, 33(2): 150-164. Boston: Pitman Publishing.

FRIEDMAN, M. (1962). Capitalism and Freedom. Chicago: The University Chicago Press. 
FRIEDMAN, A.; MILES, S. (2006). Stakeholders: Theory and practice. Oxford: Oxford University Press.

GARRIGA, E.; MELÉ, D. (2004). Corporate social responsibility theories: mapping the territory. Journal of Business Ethics, 53(12): 51-71. http://dx.doi.org/10.1023/B:BUSI.0000039399.90587.34

GLOBAL REPORTING INITIATIVE (2011). Guía para la elaboración de memorias de sostenibilidad (versión 3.1). Amsterdam.

HARRISON, J.S.; FREEMAN, R.E. (1999). Stakeholders, Social Responsibility and Performance: Empirical Evidence and Theoretical Perspective. Academy of Management Journal, 42(5): 479-485. http://dx.doi.org/10.2307/256971

INSTITUTO UNIVERSITARIO DE ANÁLISIS ECONÓMICO Y SOCIAL (2011). La RSC, de nuevo ante la incertidumbre. Madrid: Fundación Alternativas.

JENSEN, M.C. (2002). Value Maximization and the Corporate Objective Function. Business Ethics Quaterly, 12(2): 235-256. http://dx.doi.org/10.2307/3857812

LARRINAGA, C. (1997). Consideraciones en torno a la relación entre la contabilidad y el medio ambiente. Revista Española de Financiación y Contabilidad, 93: 957.

MAIGNAN, I.; FERRELL, O.C. (2001). Antecedents and benefits of corporate citizenship: An investigation of French businesses. Journal of Business Research, 51(1): 37-51. http://dx.doi.org/10.1016/S0148-2963(99)00042-9

MAIGNAN, I.; FERRELL, O.C. (2004). Corporate Social Responsibility and Marketing: An Integrative Framework. Journal of the Academy of Marketing Science, 32(1): 3-19. http://dx.doi.org/10.1177/0092070303258971

MATTEN, D.; CRANE, A.; CHAPPLE, W. (2003). Behind the mask: Revealing the true face of corporate citizenship. Journal of Business Ethics, 45(1-2): 109-120.

http://dx.doi.org/10.1023/A:1024128730308

MATTEN, D.; CRANE, A. (2005). Corporate Citizenship: toward an extended theorethical conceptualization. Academy of Management Review, 04(2003). Research Paper Series. http://dx.doi.org/10.5465/AMR.2005.15281448

MCWILLIAMS, A.; SIEGEL, D. (2000). Corporate social responsibility and financial performance: correlation or misspecification?. Strategic Management Journal, 21: 603-609. http://dx.doi.org/10.1002/(SICI)1097-0266(200005)21:5<603: :AID-SMJ101>3.0.CO;2-3

MCWILLIAMS, A.; SIEGEL, D. (2001). Corporate Social Responsibility: A Theory of de Firm Perspective. Academy of Management Review, 26(1): 117-127.

MOIR, L. (2001). What do we mean by corporate social responsibility?. Corporate Governance, $1(2): 6-22$. 
MONEVA, J.M.; HERNÁNDEZ, J.C. (2006). Responsabilidad Social Corporativa e información de sostenibilidad en las PYME. Revista Internacional de la Pequeña y Mediana Empresa, 1: 23.

MONEVA, J.M. (2007). És la Responsabilitat Social Corporativa rendible per a l'empresa? Revista de Comptabilitat i Direcció, Responsabilitat Social Corporativa, 5: 55-75.

NELLING, E.; WEBB, E. (2009). Corporate Social Responsability and Financial Performance: The virtuous circle revisited. Review of Quantitative Finance and Accounting, 32(2): 197-209. http://dx.doi.org/10.1007/s11156-008-0090-y

OBSERVATORIO DE LA RESPONSABILIDAD SOCIAL CORPORATIVA (2009). La responsabilidad social corporativa en las memorias anuales de las empresas del Ibex-35. Análisis del ejercicio 2008.

ORLITZKY, M.; SCHMIDT, F.L.; RYNES, S.L. (2003). Corporate social and financial performance: A meta-analysis. Organization Studies, 24(3): 403-441.

http://dx.doi.org/10.1177/0170840603024003910

PEÑA, D. (2002). Análisis de datos multivariantes. México: McGraw-Hill ed.

PODDI, L.; VERGALLI, S. (2009). Does Corporate Social Responsability affect the performance of firms?. Dipartimento di Scienze Economiche. Universitá degli Studi di Brescia, Discussion Paper no 0809.

PORTER, M.E.; KRAMER, M.R. (2002). The Competitive Advantage of Corporate Philanthropy. Harvard Business Review, 80(12): 56-68.

ROBERTS, P.W.; DOWLING, G.R. (2002). Corporate reputation and sustained superior financial performance. Strategic Management Journal, 23(12): 1077-1093. http://dx.doi.org/10.1002/smj.274

ROKACH, L.; MAIMON, O. (2005). The data mining and knowledge discovery handbook. Clustering methods. Tel-Aviv: Tel-Aviv University.

SUCHMAN, M.C. (1995). Managing Legitimacy: Strategic and Institutional Approaches. The Academy of Management Review, 20(3): 71-610.

SURROCA, J.; TRIBÓ, J.A.; WADDOCK, S. (2010). Corporate Responsilibity and Financial Performance: The Role of Intangible Resources. Strategic Management Journal, 31(5): 463-490.

VÁZQUEZ, O.; CORDERO, C. (2007). Análisis empírico de la información emitida por las empresas del Ibex-35 en materia de Responsabilidad Social Corporativa. Ekonomiaz, 65: 150.

WADDOCK, S.; GRAVES, S. (1997). The corporate social performance-financial performance link. Strategic Management Journal, 18(1): 77-83. 
WALSH, J.P.; WEBER, K.; MARGOLIS, J.D. (2003). Social issues and management: Our lost cause found. Journal of Management, 29: 859-881.

http://dx.doi.org/10.1016/S0149-2063(03)00082-5

WRIGHT, P.; FERRIS, S. (1997). Agency conflict and corporate strategy: The effect of divestment on corporate value. Strategic Management Journal, 18(1): 77-83.

http://dx.doi.org/10.1002/(SICI)1097-0266(199701)18:1<77: :AID-SMJ810>3.0.CO;2-R

Intangible Capital, 2014 (www.intangiblecapital.org)

Article's contents are provided on a Attribution-Non Commercial 3.0 Creative commons license. Readers are allowed to copy, distribute and communicate article's contents, provided the author's and Intangible Capital's names are included. It must not be used for commercial purposes. To see the complete license contents, please visit http://creativecommons.org/licenses/by-nc/3.0/. 